Restoration of the Hypersonic Tunnel Facility at NASA Glenn Research Center, Plum Brook Station

Mark A. Woodling

Glenn Research Center, Cleveland, Ohio 
Since its founding, NASA has been dedicated to the advancement of aeronautics and space science. The NASA Scientific and Technical Information (STI) Program Office plays a key part in helping NASA maintain this important role.

The NASA STI Program Office is operated by Langley Research Center, the Lead Center for NASA's scientific and technical information. The NASA STI Program Office provides access to the NASA STI Database, the largest collection of aeronautical and space science STI in the world. The Program Office is also NASA's institutional mechanism for disseminating the results of its research and development activities. These results are published by NASA in the NASA STI Report Series, which includes the following report types:

- TECHNICAL PUBLICATION. Reports of completed research or a major significant phase of research that present the results of NASA programs and include extensive data or theoretical analysis. Includes compilations of significant scientific and technical data and information deemed to be of continuing reference value. NASA's counterpart of peerreviewed formal professional papers but has less stringent limitations on manuscript length and extent of graphic presentations.

- TECHNICAL MEMORANDUM. Scientific and technical findings that are preliminary or of specialized interest, e.g., quick release reports, working papers, and bibliographies that contain minimal annotation. Does not contain extensive analysis.

- CONTRACTOR REPORT. Scientific and technical findings by NASA-sponsored contractors and grantees.
- CONFERENCE PUBLICATION. Collected papers from scientific and technical conferences, symposia, seminars, or other meetings sponsored or cosponsored by NASA.

- SPECIAL PUBLICATION. Scientific, technical, or historical information from NASA programs, projects, and missions, often concerned with subjects having substantial public interest.

- TECHNICAL TRANSLATION. Englishlanguage translations of foreign scientific and technical material pertinent to NASA's mission.

Specialized services that complement the STI Program Office's diverse offerings include creating custom thesauri, building customized data bases, organizing and publishing research results ... . even providing videos.

For more information about the NASA STI Program Office, see the following:

- Access the NASA STI Program Home Page at http://www.sti.nasa.gov

- E-mail your question via the Internet to help@sti.nasa.gov

- Fax your question to the NASA Access Help Desk at (301) 621-0134

- Telephone the NASA Access Help Desk at (301) 621-0390

- Write to: NASA Access Help Desk NASA Center for AeroSpace Information 7121 Standard Drive Hanover, MD 21076

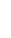


NASA/TM-2000-209930

AIAA-2000-0163

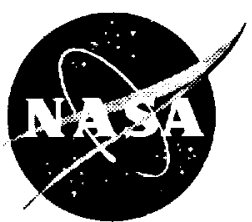

\section{Restoration of the Hypersonic Tunnel Facility at NASA Glenn Research Center, Plum Brook Station}

Mark A. Woodling

Glenn Research Center, Cleveland, Ohio

Prepared for the

38th Aerospace Sciences Meeting and Exhibit

sponsored by the American Institute of Aeronautics and Astronautics

Reno, Nevada, January 10-13, 2000

National Aeronautics and

Space Administration

Glenn Research Center 


\section{Available from}

NASA Center for Aerospace Information 7121 Standard Drive

Hanover, MD 21076

Price Code: A03
National Technical Information Service 5285 Port Royal Road Springfield, VA 22100 Price Code: A03 


\title{
RESTORATION OF THE HYPERSONIC TUNNEL FACILITY AT NASA GLENN RESEARCH CENTER, PLUM BROOK STATION
}

\author{
M.A. Woodling \\ National Aeronautics and Space Administration \\ Glenn Research Center \\ Cleveland, Ohio 44135
}

\begin{abstract}
$\underline{\text { Abstract }}$
The NASA Glenn Research Center's Hypersonic Tunnel Facility (HTF), located at the Plum Brook Station in Sandusky, Ohio, is a non-vitiated, free-jet facility, capable of testing large-scale propulsion systems at Mach Numbers from 5 to 7 . As a result of a component failure in September of 1996, a restoration project was initiated in mid-1997 to repair the damage to the facility. Following the 2-1/2 year effort, the HTF has been returned to an operational condition. Significant repairs and operational improvements have been implemented in order to ensure facility reliability and personnel safety. As of January 2000, this unique, state-of-the-art facility was ready for integrated systems testing.
\end{abstract}

\section{Introduction and Facility Description}

The NASA Glenn Research Center's Hypersonic Tunnel Facility (HTF) is located at the Plum Brook Station in Sandusky, Ohio. The HTF is a blow-down, non-vitiated, free-jet facility capable of testing largescale propulsion systems at Mach numbers up to $7^{1}$. Hypersonic engines, and other models up to 10 feet in length and 2 feet in diameter, can be accommodated within the test section. Testing features include the ability to provide true temperature, pressure, and air composition for Mach numbers 5 through 7. A large steam-driven ejector evacuates the test cabin and provides altitude simulation. The operating envelope for the HTF is shown as Figure 1. A facility isometric diagram and a component illustration are presented as Figures 2 and 3.

The driving fluid for the tunnel is pressurized gaseous nitrogen. A 663,000 standard cubic foot, 4500 psig rated, railroad tank car is located adjacent to the facility $^{2}$. Nitrogen flows up to $130 \mathrm{lbm} /$ second, and pressures up to $1200 \mathrm{psig}$, can be supplied to the facility via the tank car.

The gaseous nitrogen is ported to a vertically oriented, 3 MW cylindrical induction heater that is approximately $40 \mathrm{ft}$. in height by $10 \mathrm{ft}$. in diameter (see Figure 4). The inductively heated core of the heater consists of fifteen cylindrical, graphite susceptor blocks, stacked one-on-top-of-the-other. Each susceptor block is $6 \mathrm{ft}$. in diameter by $2 \mathrm{ft}$. in height, and has 1945 holes (ranging between 0.75" and 1.125" in diameter) drilled axially through the block. As the blocks are stacked to form the core, hexagonal graphite keys are installed at each block interface to orient the drilled holes. The perimeter of each susceptor block is wrapped with a 10 inch thick layer of graphite felt insulation. A cylindrical, 2 inch thick silicon tile wall surrounds the susceptor block/graphite felt core.

A 4-piece, water-cooled, helical copper coil surrounds the susceptor block/graphite felt core and generates the inductive field. Each helical coil is fabricated from $1-5 / 8$ inch diameter copper tubing with a wall thickness of 0.25 inches. Current is passed through the copper cross-sectional area of the tubing, using a 180 hertz, single phase, 750 volt power source. De-ionized water is pumped through the internal diameter to cool the coil and other components within the heater. The induced field resistively heats the outer 4 inches of the susceptor block ${ }^{1}$. The remainder of the block increases in temperature as heat conducts radially through the graphite towards the block centerline.

Heating of the 60,000 pound graphite core must be done slowly to minimize thermal stresses within the susceptor blocks. Consequently, heating of the core, from ambient temperature up to $4600{ }^{\circ} \mathrm{R}$ (maximum temperature), can take up to 100 hours. Each of the four sections of the induction coil can be independently controlled to accomplish desired temperature gradients throughout the heater. Susceptor block surface temperatures are measured at scheduled time intervals with portable pyrometers and the induction coil control is performed manually.

The heated nitrogen gas exits the top of the induction heater and flows through a series of bolted, watercooled components that are collectively referred to as the "hot train" (see Figure 3). The hot gas flows through the 18-inch bore of these assembled. components which consist of: 
- A ball valve. This component is used only as a spool-piece, and is not an operational valve.

- The graphite-lined Hot Tee.

- The Radiation Shutter Valve (RSV).

- The Diluent Injection Flange. Three flanges exist, one for each Mach number condition (5, 6, and 7).

- The film cooling flange

- The mixing section.

- The adapter flange.

- The facility nozzle. Three nozzles exist, one for each Mach number condition.

When a tunnel run is initiated, up to $130 \mathrm{lbm} /$ second of nitrogen gas is ported through the induction heater. As the hot nitrogen exits the heater and flows through the hot train, an ambient temperature gaseous oxygen and gaseous nitrogen mixture is introduced into the flow stream through the Diluent Injection Flange. An analog flow computer is used to meter the diluent flow rates and oxygen/nitrogen compositions that are injected into the flow stream. Since the temperature of the nitrogen exiting the heater gradually decreases with time (as the storage heater core temperature drops), the diluent flows must be metered to compensate for the changing conditions. Through a complex series of control logic, synthetic air is produced with "true air" chemical composition and total temperature conditions to match the desired Mach number.

The hot nitrogen and the injected diluent gases are ported through a water-cooled mixing section prior to entering the water-cooled converging-diverging nozzle. Each of the three facility nozzles has a 42 -inch exit diameter with internal contours that expand the flow to the desired Mach 5, 6, or 7 conditions. The outlet of the nozzle protrudes through the wall of the domed, cylindrical test cabin, which is 25 feet in diameter and 20 feet in height. A supersonic diffuser penetrates through the wall of the test cabin opposite of the facility nozzle outlet.

The test article is mounted on an overhead, translating thrust stand located between the nozzle outlet and the diffuser. The test article can be translated up to 30 inches along the free-jet axis and can be hydraulically pivoted to a $5^{\circ}$ angle of attack ${ }^{3}$. The thrust stand is designed to accommodate a test article weighing up to 16,000 pounds and capable of producing 8,500 pounds of thrust.

Altitude simulation within the test cabin and exhausting of the test article combustion products is accomplished using a diffuser/steam ejector system. This system consists of a supersonic diffuser, a subsonic diffuser, a spray cooler, and a single stage steam ejector. The supersonic diffuser consists of a translatable, water-cooled, 48-inch diameter inlet collection cone followed by a constant diameter section 30 feet in length and 43 inches in diameter. The subsonic diffuser incorporates water spray nozzles designed to cool the exhaust gases to saturation temperatures. The single stage steam ejector uses a coaxial nozzle and consumes $500 \mathrm{lbm} / \mathrm{second}$ of steam at $130 \mathrm{psig}$. Steam is supplied to the ejector through a 30 -inch diameter pipeline, which connects the ejector to five 500 psig steam accumulators with a combined useful capacity of 140,000 pounds of steam. The accumulators are located roughly 1800 feet from the HTF Facility.

\section{HTF Facility History}

The present Hypersonic Tunnel Facility configuration is actually a retrofit of an original facility. In 1965, ground was broken, at the present HTF site, for a test cell called the Hydrogen Heat Transfer Facility (HHTF). Included in the HHTF construction project was the installation of a 40 -foot high by 10 -foot diameter induction furnace that featured a graphite pebble-bed susceptor core. In 1968, the Hypersonic Research Engine (HRE) Program required a facility for propulsion testing of hardware. Modifications were designed to convert the HHTF to a horizontally configured hypersonic tunnel. In 1969, the new test cabin, the steam ejector train, and the spray cooler were installed. In 1970, the graphite pebble-bed susceptor core was replaced with the solid graphite block core. Also in 1970, the model thrust stand and the horizontal hot train components were installed. By July of 1971 , the facility was ready for calibration testing.

In 1974, in accordance with a NASA Headquarters mandate, Plum Brook Station was placed in a "standby" condition. At HTF, water-cooling systems were drained and purged, and the induction heater was sealed and pressurized with nitrogen. Heat was maintained within some of the electrical equipment rooms and the control room. The facility remained dormant until the early 1990s.

In the late 1980 s, a positive response to a facility study initiated a project to reopen the facility. From 1990 to 1993, repairs were made to the steam system, the water-cooling systems, and the gaseous oxygen system. All of the high-pressure gas storage bottles were recertified in accordance with ASME codes. Also, the facility controls and the steam boiler controls were refurbished. Facility integrated systems tests were initiated in 1994 and 1995. In July of 1996, the first series of propulsion tests at conditions up to Mach 6.6 were performed. 
In September of 1996, during a test run at Mach 7 conditions, a failure occurred with the RSV. Hot gaseous nitrogen, at a $4,040{ }^{\circ} \mathrm{F}, 1,050 \mathrm{psig}$, and $125 \mathrm{lbm} / \mathrm{second}$, was flowing through the RSV at the time of the failure. Cooling water passages in all three of the major RSV components were breached by the hot gas. Upon loss of cooling water, the upper portion of the valve melted and the top half of the shutter blade (and part of the actuator package) was ejected from the hot train. Cooling lines, both upstream and downstream of the breach points, also melted and created several additional sights where hot gaseous nitrogen exited the hot train. The cabin and the test article were not damaged.

When the RSV cooling water system was breached, the water-cooling systems feeding other HTF components were interrupted. Most significantly, the water flow through the $\mathrm{GN}_{2}$ heater induction coil was lost. Consequently, damage was sustained to the induction coil and the susceptor core.

\section{$\underline{\text { Restoration Project Overview }}$}

In July of 1997, the HTF restoration project was initiated. The work scope for this project was developed from the following items:

- Restore all facility hardware damaged as a result of the RSV failure.

- Institute more health monitoring into the critical facility systems. Also, implement better abort monitoring and data time stamping into the controls systems.

- Re-design critical water-cooling systems to include separate water supply/retum circuits (with automatic isolation valves) for each component.

- Use modern computer software to analyze the structural and thermal conditions occurring within critical HTF components.

- Use modern computer software to create a dynamic thermal model of the induction heater core. This model would be used to modify operational procedures to minimize thermal stresses in the susceptor blocks. Also, the model would be used as a tool to optimize heater performance and to predict gas exit conditions.

- Perform chemical analysis to better understand the effects of purge gases and contaminant interactions with the graphite susceptor core at high temperatures. This would be used to implement better gas monitoring systems within the heater and to optimize the purge gas operations.
Upon completion of the restoration project, all of the damaged HTF components had been repaired or replaced with new, improved components. Also, the project team addressed many issues that were known HTF historical problem areas. These improvements were accomplished by providing either improved hardware, modified operating procedures, or improved health monitoring and data logging. As of January 2000 , operations personnel are preparing to perform the integrated systems tests for the rebuilt facility.

\section{Refurbished Induction Coil}

As indicated previously, the four-piece induction coil sustained some damage when cooling water was interrupted as a result of the RSV failure. Much of the electrical insulation had been damaged, and many of the bronze support studs, which bolt the copper coil to the structural support members, had failed. The design team was also concerned that the intense heat could have caused metallurgical changes in the copper. However, in-house inspections and material tensile tests verified that the base copper material was sound and could be utilized for the rebuilt coil.

The original coil fabricator was used as a consultant for the repairs. Following a thorough design process, the following modifications were made to the coils:

a) Modern, sprayed-on electrical insulation was applied to the coil in lieu of the insulation tape used on the original coil.

b) The original support structure boards had been fabricated from transite (asbestos). A composite board, consisting of fiberglass fibers in a polyester resin, was used in lieu of the transite.

c) Based upon the electrical requirements for the coil (180 hertz power), the design team was concerned about electrically induced vibrations that could reduce the fatigue life of the support studs. Consequently, the existing brass studs were replaced with larger diameter, copper-welded silica-bronze studs. Approximately 4000 studs were replaced on the four coil sections.

During the repair procedures, a bead-blasting process was used to remove what remained of the old insulation off of the copper coils. Upon completion of this process, the copper joints in the coil were exposed. As discussed previously, the helical induction coil was originally fabricated from 1-5/8 diameter copper tubing having a 0.25 inch wall thickness. The coil was built by brazing several 20 -foot lengths of the tubing together and winding the tubing around a mandrel. 
Consequently, each of the four coil sections contained roughly 7 brazed joints (sum total of 29 joints for the 4 coils). When pressure testing was performed on the bare coils, leaks were identified at some of the joints. Based on chemical analysis, it was determined that coil leakage during heater operations could lead to graphite susceptor block degradation ${ }^{4}$.

The induction coils typically must survive an $80 \mathrm{psig}$ internal operating pressure (cooling water pressure) and a 1,200 psig maximum external pressure exerted by the flowing nitrogen gas. Based upon these conditions, the project team performed ASME B31.3 calculations to determine if the existing joints were structurally sufficient. Upon review of the results, a determination was made to replace every copper brazed joint with a copper welded joint. Since the chemical analysis had recommended that the total water vapor content within the heater be kept below $10 \mathrm{ppm}$, each joint was $100 \% \mathrm{x}$-ray inspected to ensure weld integrity. Figure 5 shows the wood fixtures used to support the coils during the joint welding procedures.

Once the joint welding was completed and the new support studs were welded to the outer diameter of the tubing, the bare coil was leak tested. A plastic tent was built around the coil and filled with gaseous helium. A vacuum was pulled on the internal diameter of the coil, and the contents were analyzed by Mass Spectrometry. The coil sections were then subjected to a hydrostatic test at $\mathbf{1 . 5}$ times the maximum operating pressure.

Finally, the new coil insulation was applied in a spray booth. Following a continuity test to ensure the integrity of the insulation, the coils were packaged and shipped to Plum Brook Station.

Figure 6 shows the refurbished coils being installed within the heater pressure vessel. Upon completion of the coil installation, a leak test with helium was performed again to ensure that no damage had occurred during shipping or installation. The de-ionized water inlet and outlet piping was then connected to the coils. As a final check, the entire system was successfully hydrotested again at 1.5 times the maximum operating pressure.

\section{Restored Graphite Susceptor Core and Redesigned Heater Hardware}

Following the RSV failure, the 15 susceptor blocks were removed from the induction heater. Inspection of the blocks indicated that the two upper-most susceptor blocks had cracks in the webbing between the holes and on the outer surface, and seven susceptor blocks showed signs of significant perimeter erosion. Also, the graphite transition cone, located at the top of the susceptor core, sustained a deep crack all the way through the thickness of the cone. The six bottom-most blocks did not sustain any damage and were therefore considered to be reusable.

Figure 7 shows several of the newly machined susceptor blocks that were delivered to Plum Brook Station. As previously discussed, prior to installation, each block was wrapped with a 10-inch thick graphite blanket. These blankets were fabricated by stitching together multiple layers of graphite felt material. Figure 8 shows the susceptor blocks wrapped with the blankets. Prior to installation within the heater, the blankets were compressed with perimeter restraints attached to "release strings". Once a block was placed within the heater, the strings were pulled which released the restraints and allowed the blanket material to expand and fill the annular space between the perimeter of the block and the silicon tile wall.

The susceptor core of the heater is supported from the bottom of the heater vessel by a round carbon steel pedestal. This pedestal consists of a ring-shaped vertical flange welded to a flat horizontal flange. The horizontal flange supports the outer 3 inches of the bottom-most susceptor block. The horizontal and vertical flanges of the pedestal were isolated from the hot susceptor block with insulation pads. Since the heater purge gas inlet ports are located near the bottom of the heater, the flowing gas provides convective cooling of the pedestal.

During previous operations, thermocouples mounted on the pedestal had typically indicated high flange temperatures. This had forced operations personnel to maintain lower temperatures in the bottom blocks, which reduced the overall thermal capacity of the heater. When the heater was disassembled, it was found that the horizontal and vertical insulation pads were flattened and were not providing sufficient thermal protection.

MSC.Patran THERMAL computer software was used to model the steady-state thermal conditions occurring at the bottom of the heater. The software model was calibrated using actual thermocouple data from previous heater operations. This model indicated that, due to thermal growth of the bottom block, there was minimal clearance between the outer perimeter of the block and the vertical flange of the steel pedestal ring. As a result of this finding, the thickness of the vertical flange (which was not a structural member) was reduced on a milling machine to provide more clearance. Also, a new insulation pad was designed to 
insulate the horizontal flange. A rigid carboncomposite board, having an excellent compressive strength and good thermal resistance properties, was used for the pad fabrication.

During the modeling of the lower heater components, high temperatures were also identified in another heater component called the baffle plate. This component, located above the gaseous nitrogen inlet port at the bottom of the heater, is used to evenly distribute the incoming nitrogen gas across the bottom face of the first susceptor block. The baffle plate consisted of a stainless steel disc supported by three posts and protected from thermal radiation by a shield incorporating fibrous insulation. Although not in direct contact with the hot susceptor blocks, the baffle plate was located very close to the bottom-most block, and therefore heated up due to the intense radiation heat transfer. This plate is also subjected to a high thermal shock when the hot surfaces are exposed to the $130 \mathrm{lbm} /$ second of in-rushing cold nitrogen during a tunnel nun.

Using the thermal model to validate concepts, the baffle plate was replaced with a new design that incorporated a disc and support posts fabricated from inconel 718 and a radiation shield fabricated from the rigid carbon-composite board. The radiation shield was offset from the disk to minimize paths for conduction heat transfer.

\section{Revised Heater Purge Gas Procedures}

In order to better understand the high temperature interactions of heater contaminants (i.e. oxygen, water vapor, etc.) and purge gases with the graphite susceptor core, a thorough chemical analysis was performed. Historically, there had been concerns regarding the facility procedures for drying out the heater bed prior to heating to maximum temperatures. Also, since high temperatures are maintained within the heater for long periods of time prior to a tunnel run, there was a concern that the heater purge procedures could actually be a contributor to susceptor block degradation.

Glenn in-house personnel performed the chemical analysis and presented the conclusions in a detailed report ${ }^{4}$. It was recommended that water vapor content within the heater be maintained below $10 \mathrm{ppm}$ to minimize oxidation damage to the graphite. The report also concluded that the nitrogen purge gas, at temperatures above $2000^{\circ} \mathrm{F}$, could have adversely reacted with the graphite to cause consumption of the material.
As a result of the report recommendations, the following modifications were made:

a) New heater "bake-out" procedures were developed that incorporate heat up and evacuation (with a vacuum pump) operations.

b) A modern gas analyzer system was installed to sample the atmosphere within the heater. Operational "red-line" conditions were established for oxygen and water vapor content.

c) The heater purge gas system was modified to incorporate a helium gas purge when the core temperature exceeds $2000^{\circ} \mathrm{F}$. Helium gas was also considered favorable due to its superior cooling properties (could keep the pedestal and baffle plate cooler).

The report also suggested that the small amounts of water leakage from the original induction coil could have caused graphite degradation. Consequently, the extensive coil joint repairs, which were validated by stringent leak testing procedures, will improve the life of the core.

\section{Redesigned Radiation Shutter Valve}

Being the "failed component", the RSV received a high level of scrutiny. The design team was faced with some basic decisions that needed to be addressed including:

a) Rebuild the facility with no RSV.

b) Replicate the original design.

c) Design a modified version of the original design.

d) Consider a completely new radiation shield concept.

A design decision matrix was used to evaluate the four possibilities. Each concept was graded on the basis of:

- design/fabrication cost

- design/fabrication schedule impact

- operational complexity

- maintenance requirements

- personnel safety

- risks to the $\mathrm{GN}_{2}$ heater

- operational costs

After compiling a composite score, the team decided to pursue a modification of the original design (option "c" above). 
Although the traditional three-piece, gate-valve style design was replicated in the redesign, many significant improvements were implemented. During the mishap investigation, thermal analysis identified problem areas within the water-cooling liners surrounding the 18-inch bores of the two valve body halves. High bolt torque values (required to clamp the valve to its adjacent components) were restraining areas on the body halves which were experiencing thermal growth due to high temperature gradients. Subsequent structural analysis of these areas indicated stress values well above ASME Code allowables. Consequently, the team redesigned the water-cooling liners to incorporate a bellows-style expansion modification. Thermal and structural analysis verified ASME Code compliance for the revised design.

Another significant RSV design modifications involved the implementation of double O-rings seals. These seals were designed at both the stationary valve surfaces and the surfaces between the sliding shutter blade. The annular spaces between the O-rings is pressurized with nitrogen at a pressure slightly higher than the internal flowing fluid pressure. The cavity pressure is continually monitored and historically logged and compared so that O-ring integrity can be assessed.

A variety of additional design improvements were implemented including:

a) Externally adjustable rollers were installed within the valve body halves to ensure smooth blade travel.

b) The actuator was designed with an oversized hydraulic cylinder capable of producing additional force to close the valve in the event of blade binding.

c) The blade hydraulic actuator was designed with a spherical joint and trunions to minimize eccentric loading on the blade during translation.

d) The hydraulic actuator cylinder force is measured and monitored to indicate binding problems.

e) Shields have been installed, at the top and bottom of the valve body. These shields are purged with $\mathrm{GN}_{2}$ to minimize air ingestion into the hot train.

f) An improved thermal barrier coating was applied to the internal bore surfaces of the two valve body halves and the blade.

The fabricated RSV was subjected to a variety of tests to validate the design conditions. All internal water passages on the valve were hydrostatically tested at 1.5 times the operating pressure. The valve was also bolted to the hot tee (valve in the open position) and the entire assembly was hydrostatically tested to
1.5 times the operating pressure. The valve blade differential pressure design was also validated with a hydrostatic test.

Upon completion of the structural verification testing, valve functional testing was initiated. The actuator package was attached to the valve body and the entire assembly was mounted in a customized stand (see Figure 9). A portable hydraulic unit was used to test and adjust all of the hydraulic functions. The blade travel distance was adjusted to ensure proper seating, and the stoke-time was set to 7 seconds.

Finally, a series of "stroke tests" were performed to check the repeatability of all measurements and to test the O-ring cavity seal gas integrity. By stroking the valve multiple times and then performing a pressure decay test on the O-ring seals, the design team was able to baseline a seal leakage rate to be used for valve operations. Following the stroke tests, the shutter blade was removed and sent to the NASA Glenn Inspection Department. The blade flatness values were base-lined for future comparison and the blade was reinstalled into the valve body. The assembled valve was then sent to Plum Brook for installation into the refurbished hot train (see Figure 10).

\section{Redesigned Water Cooling Systems}

Originally, many of the HTF heater and hot train components were supplied cooling water in a series fashion from a common de-ionized water source. Consequently, when the RSV failed, collateral damage was sustained by other HTF components due to lost cooling water flow. Also, if electrical power was lost to the facility during tunnel operations, the back-up source of cooling water to the facility was the Plum Brook Raw Water System. This system, which is mainly used at the base for fire protection, supplies minimally filtered untreated water from nearby Lake Erie. Therefore, if the backup cooling water system were activated, many of the component cooling water jackets could experience clogging from entrained dirt particles and debris.

A significant portion of the restoration project was devoted to a redesign of these water systems. A new system was implemented that incorporates separate water supply and return loops having remotely actuated isolation valves. Separate circuits were provided for the heater water jackets and the induction coil, the heater exit components, the RSV, and the hot train components. In addition, automatically controlled diesel pumps were installed, fed from the de-ionized water tank, to back up the primary electric motor driven water pumps. In the new configuration, the Raw 
Water System is used only as means of backup if both the primary and backup diesel pumps fail, or if there is a problem with the de-ionized water reservoir.

The redesigned water system piping and components were hydrostatically tested at 1.5 times the maximum operating pressure. In addition, circuit setter devices were adjusted to ensure that designed water flow rates were supplied to critical components through all of the cooling loops. Since a significant amount of water temperature, pressure, and flow rate health monitoring instruments were added to the system, all instrument signals were checked during facility "dry run" test procedures. Lastly, the startup operation of the diesel pumps was verified to ensure that minimal time delays would occur when backup cooling water was required.

\section{Modified Facility Controls System}

The original HTF controls system utilized hard-wired relay logic for most of the control loops. Although this was a very effective system that worked well for many years, there were several limitations inherent within the system that precluded its future use:

a) Following the RSV failure, there was a desire to add a significant amount of new facility health monitoring instrumentation. The old system had very limited input/output expansion capability.

b) Another desire, resulting from the failure, was to implement facility data time stamping capability and abort sequence monitoring. Implementation of these features into the hard-wired system would have been very costly.

Consequently, all of the old relay panels were removed and replaced with modern programmable logic controller-based input/output cards, controls hardware, and ladder-logic software. Also, the facility control room, which is located roughly $1 / 4$ mile from the facility, was significantly modified. "Hard" push button devices, switches, and control panels were replaced with PC interfaces with interactive software controls. As a result of the controls hardware and software modifications, the data time stamping and abort monitoring features could be implemented and all of the new health monitoring signals could be accommodated.

\section{Conclusion}

The HTF, a unique and valuable national asset, has been completely restored to its original operating capability. The recent restoration project has been successful in not only repairing the damage caused by the RSV failure, but in improving operational reliability. By using modern computer tools to understand the complex structural, thermal, chemical, and fluid flow characteristics of the HTF and its components, significant hardware improvements have been implemented. Also, procedural modifications have been made to prolong the life of the induction heater core, and to reduce overall facility operating costs. Increased facility instrumentation will also enable operations personnel to better monitor component status and predict possible problems and thus avoiding future failures.

\section{References}

1. Thomas, S.R.; Woike, M.R.; and Pack, W.D.: Mach 6 Integrated systems Tests of the NASA Lewis Research Center Hypersonic Tunnel Facility. NASA TM-107083, December 1995.

2. Thomas, S.R.; Trefny, C.J.; and Pack, W.D.: Operating Capability and Current Status of the Reactivated NASA Lewis Research Center Hypersonic Tunnel Facility. AIAA Paper 956146, April 1995 (NASA TM-106808).

3. Perkins, H.D.; Thomas, S.R.; and Pack, W.D.: Mach 5 to 7 RBCC Propulsion System Testing at NASA-LeRC HTF. AIAA Paper 97-0565, January 1997 (NASA TM-107384).

4. Jacobson, N.S.: Plum Brook Hypersonic Tunnel Facility Graphite Furnace Degradation Mechanisms. NASA/TM-1999-208907, March 1999. 


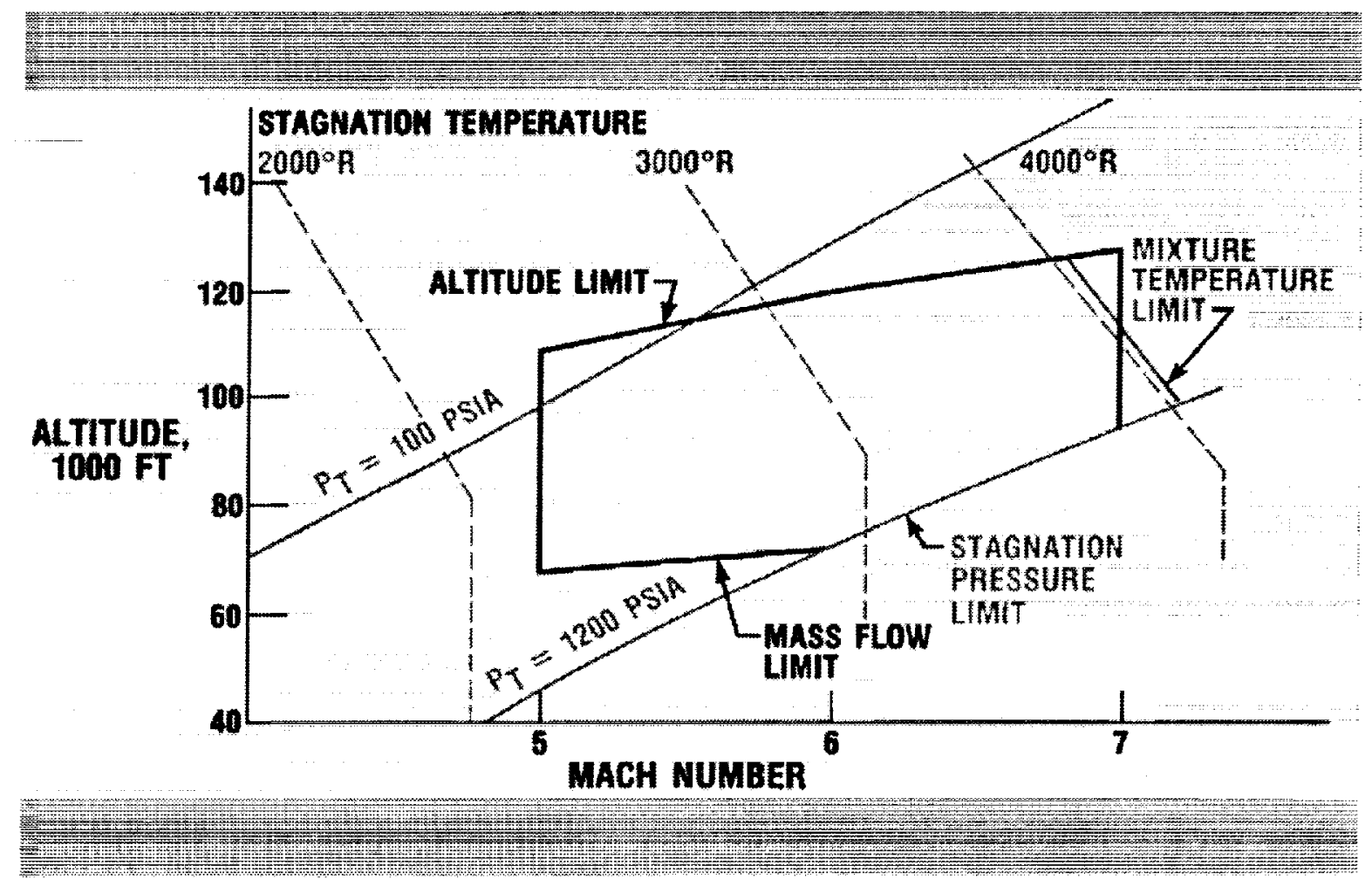

Figure 1.-Hypersonic Tunnel Facility Operating Envelope.

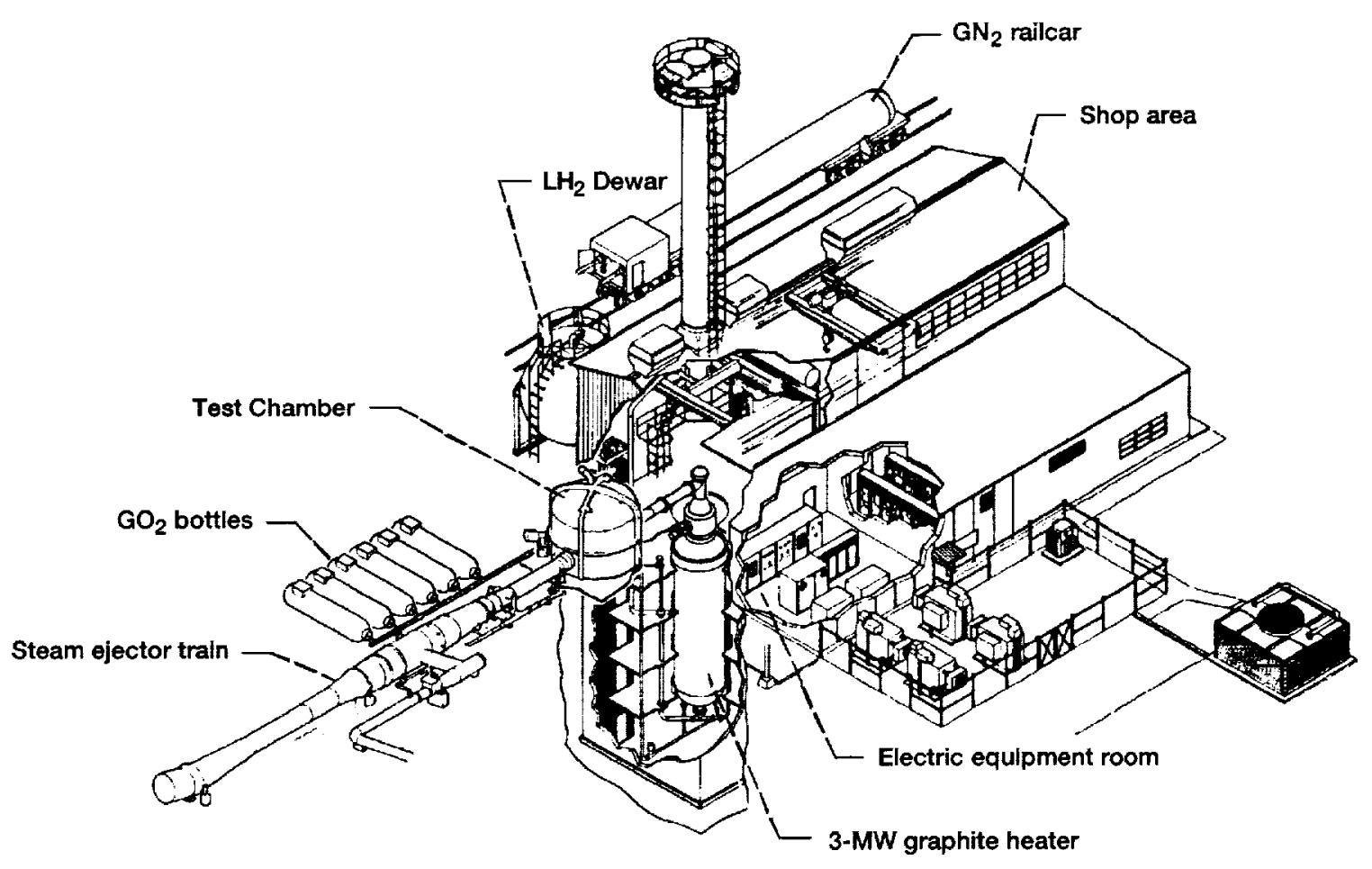

Figure 2.-Hypersonic Tunnel Facility, Isometric View of Facility. 


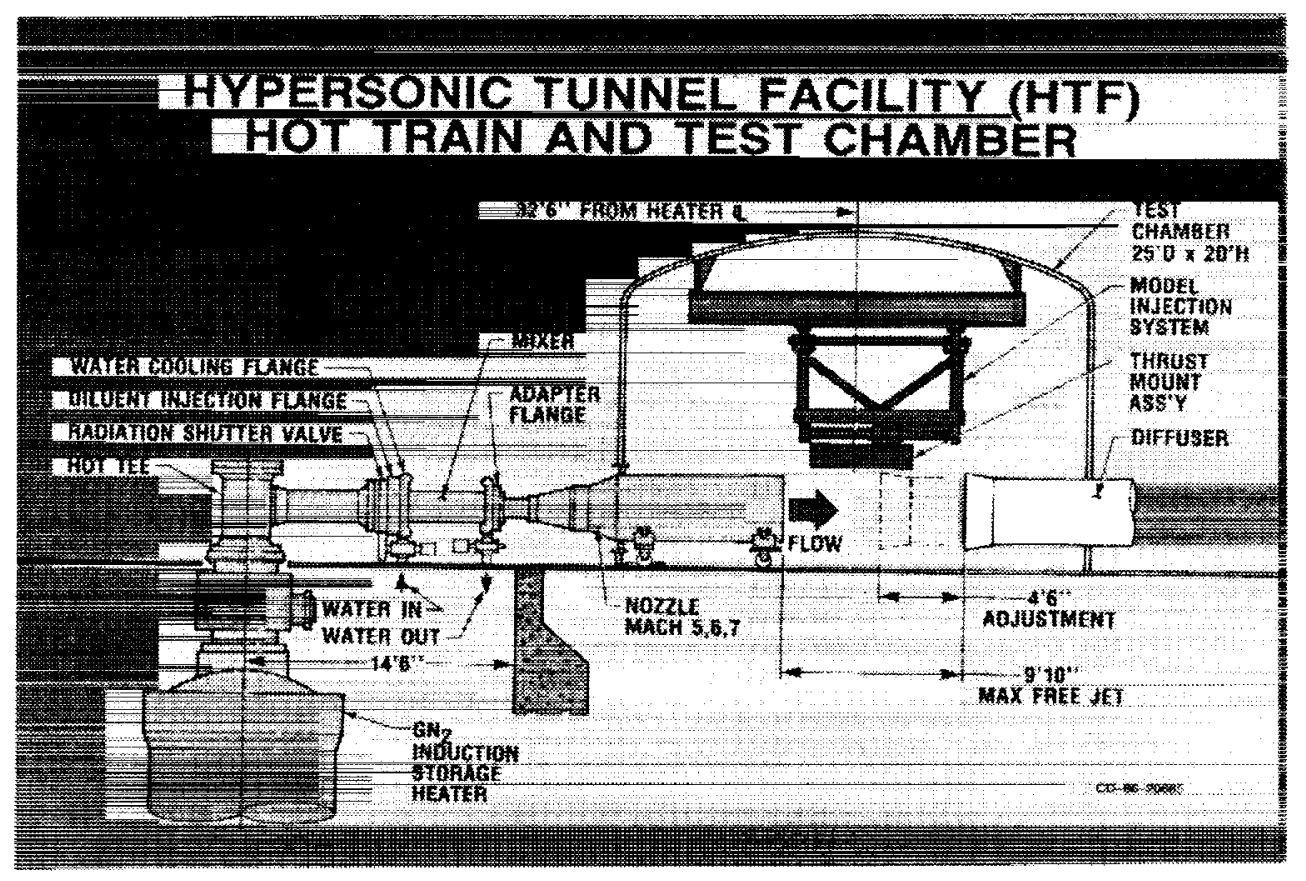

Figure 3.-HTF Component Illustration, Hot Train and Test Cabin.

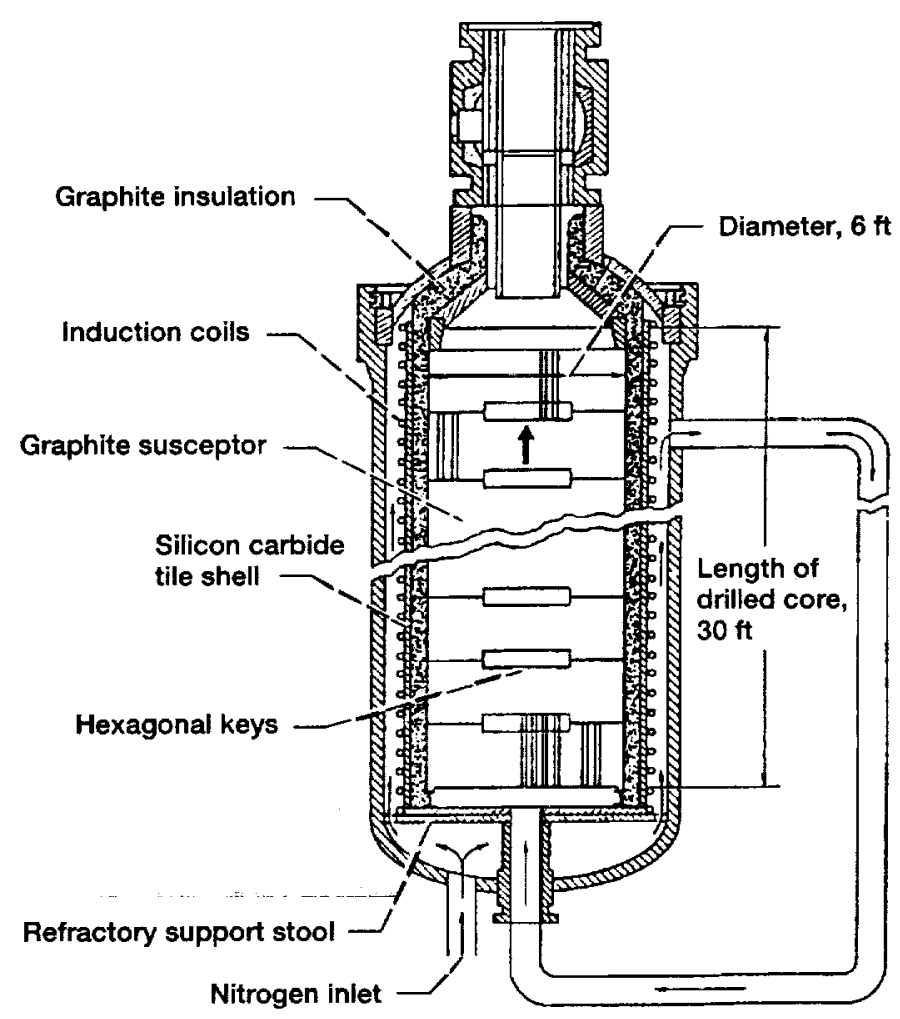

Figure 4.-HTF Gaseous Nitrogen Induction Heater. 


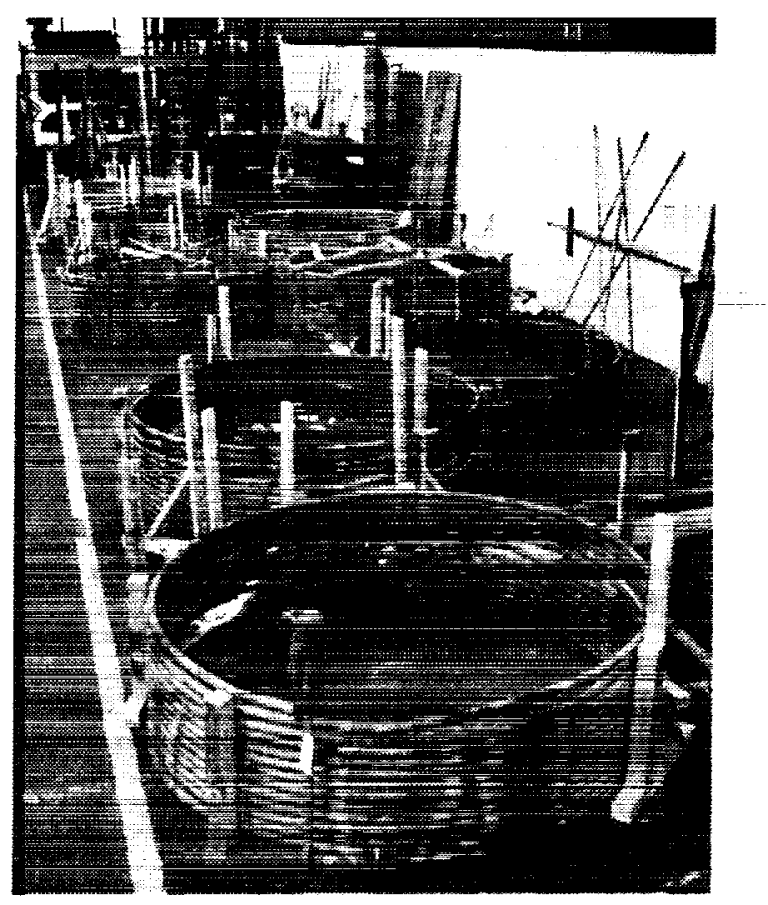

Figure 5.-HTF induction coils in wood fixtures during joint welding. Note that each of the four major coil sections have been separated into smaller sections.

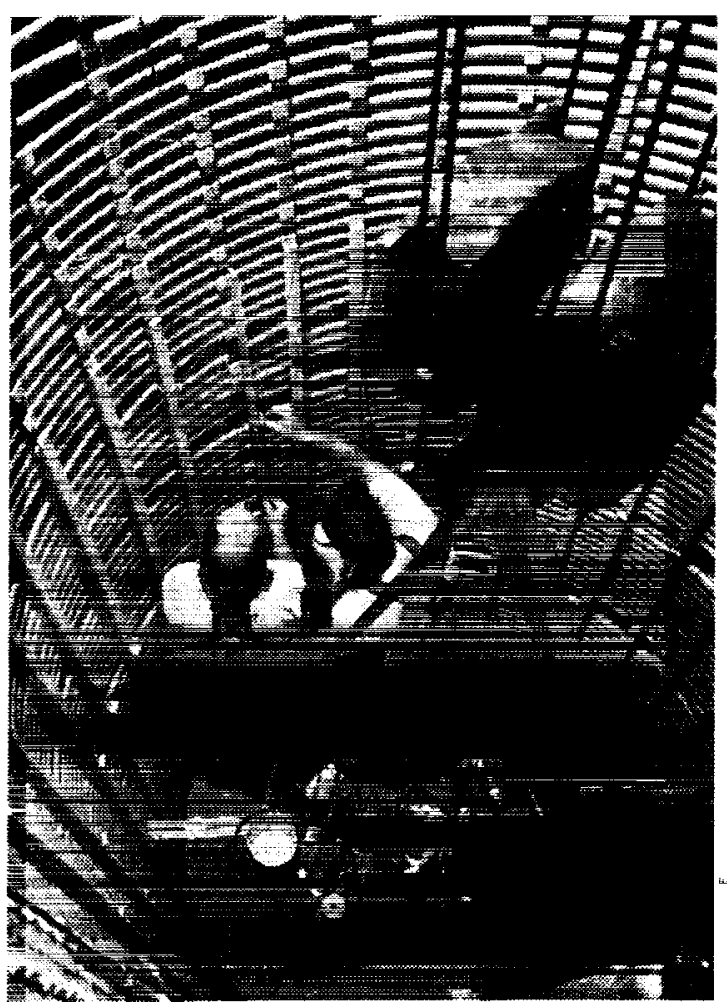

Figure 6.-Refurbished induction coils being installed within the heater pressure vessel at the HTF site, Plum Brook Station, Sandusky, Ohio. 


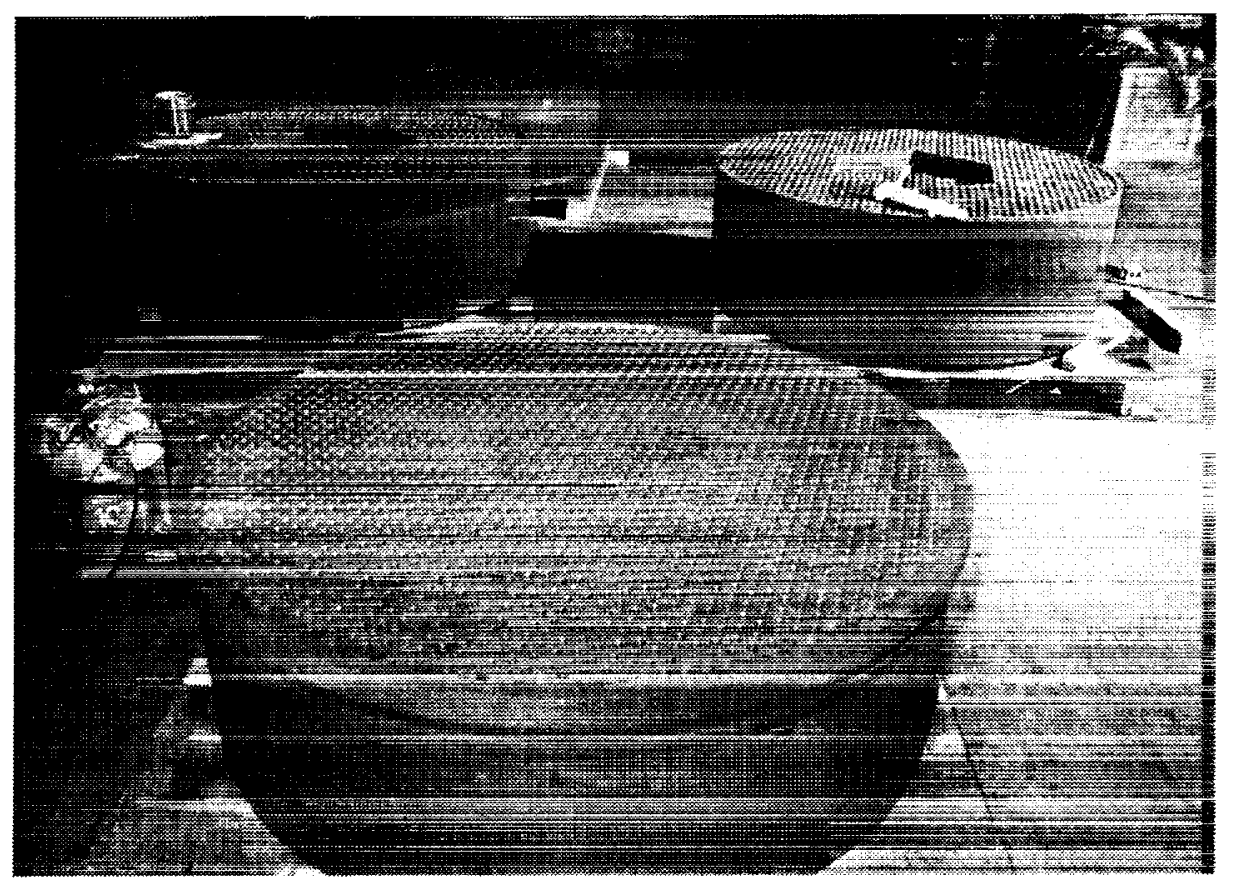

Figure 7.-Newly machined graphite susceptor blocks.

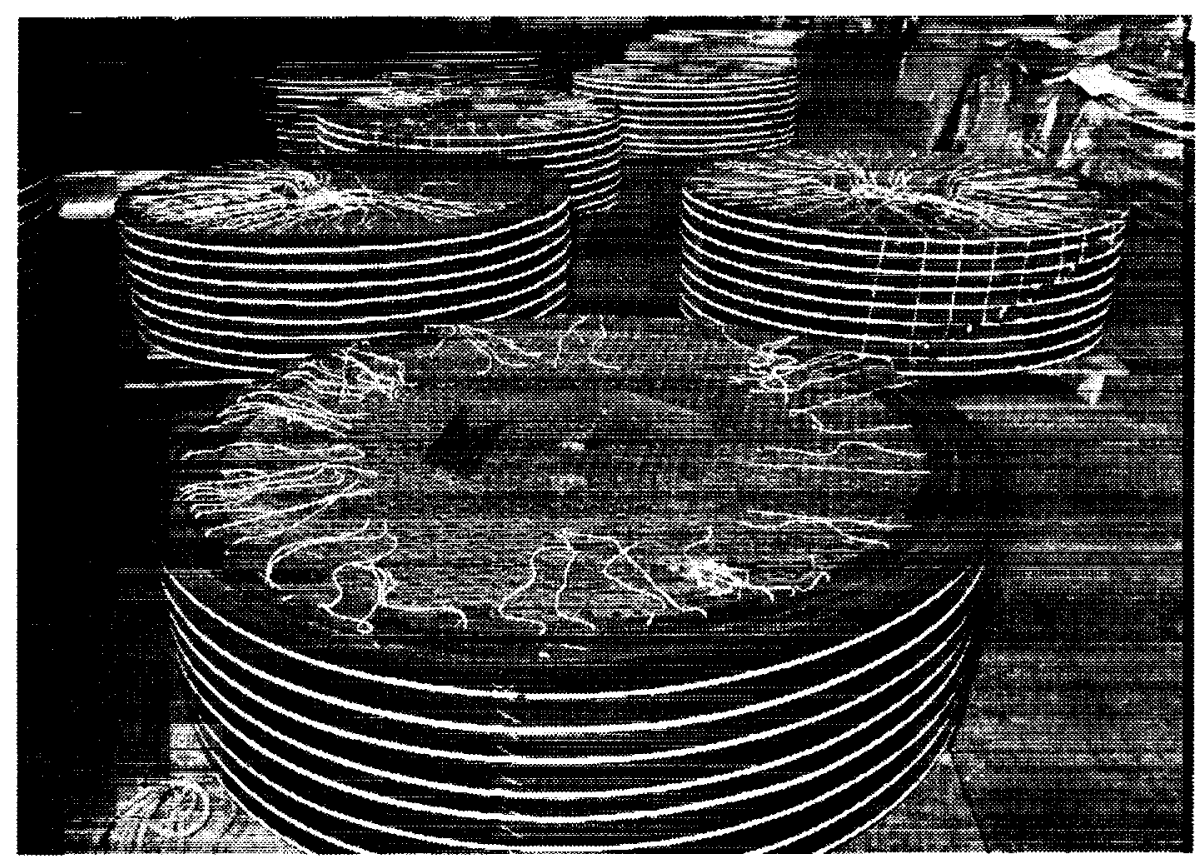

Figure 8.-Graphite susceptor blocks wrapped with graphite blankets. 


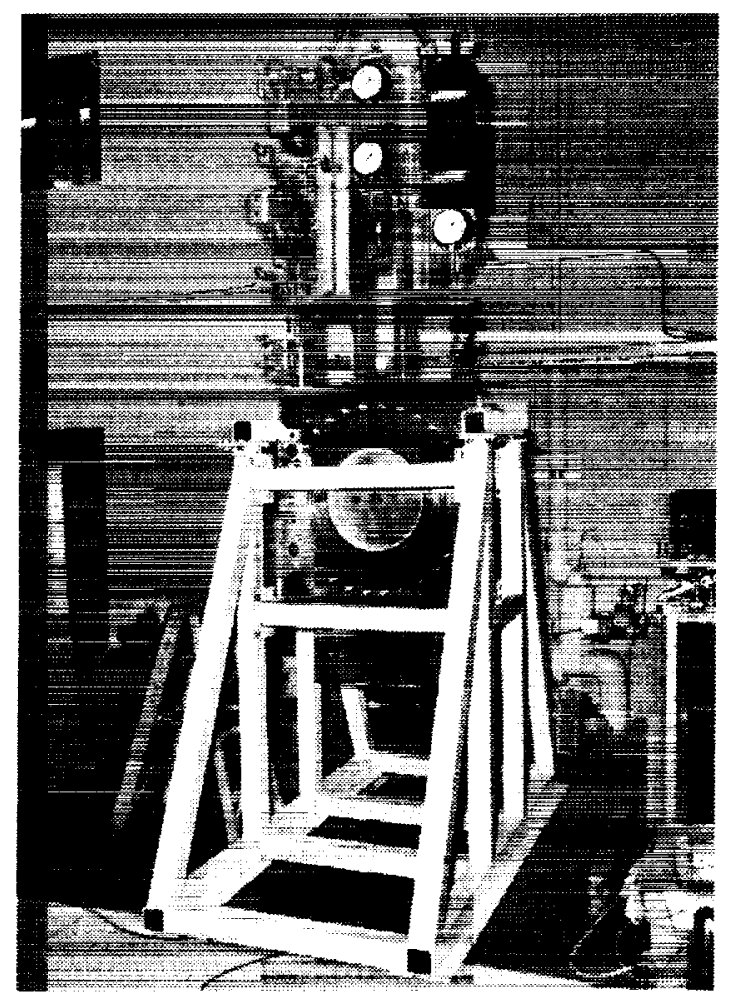

Figure 9.--Redesigned Radiation Shutter Valve (RSV) mounted in a stand for functional testing.

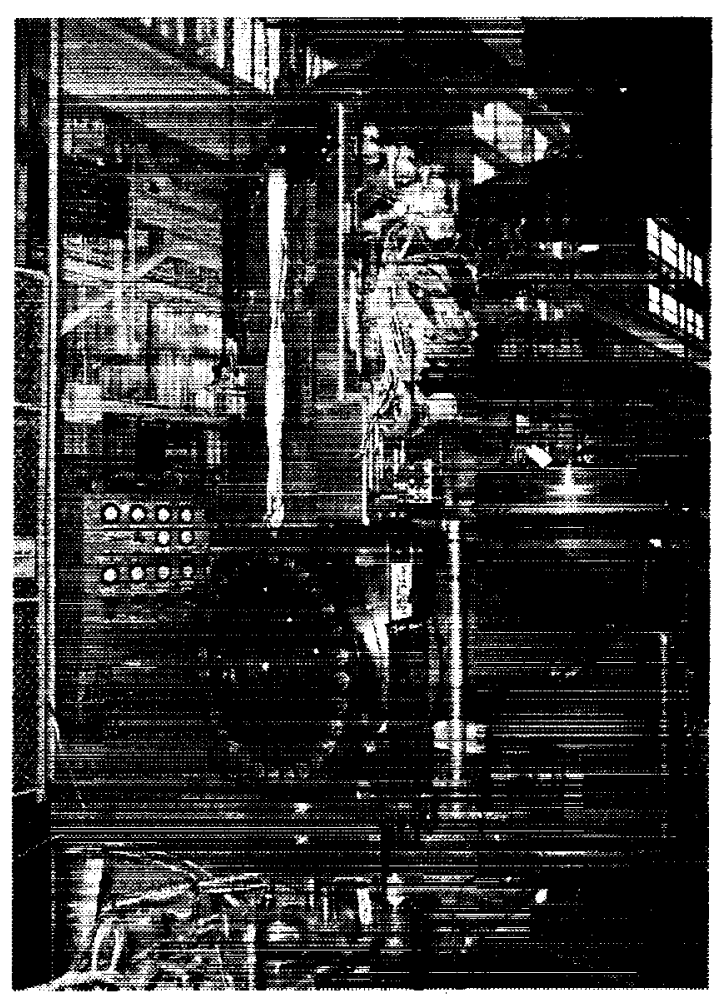

Figure 10.- Redesigned Radiation Shutter mounted on the Hot Tee at the HTF Site, Plum Brook Station. 


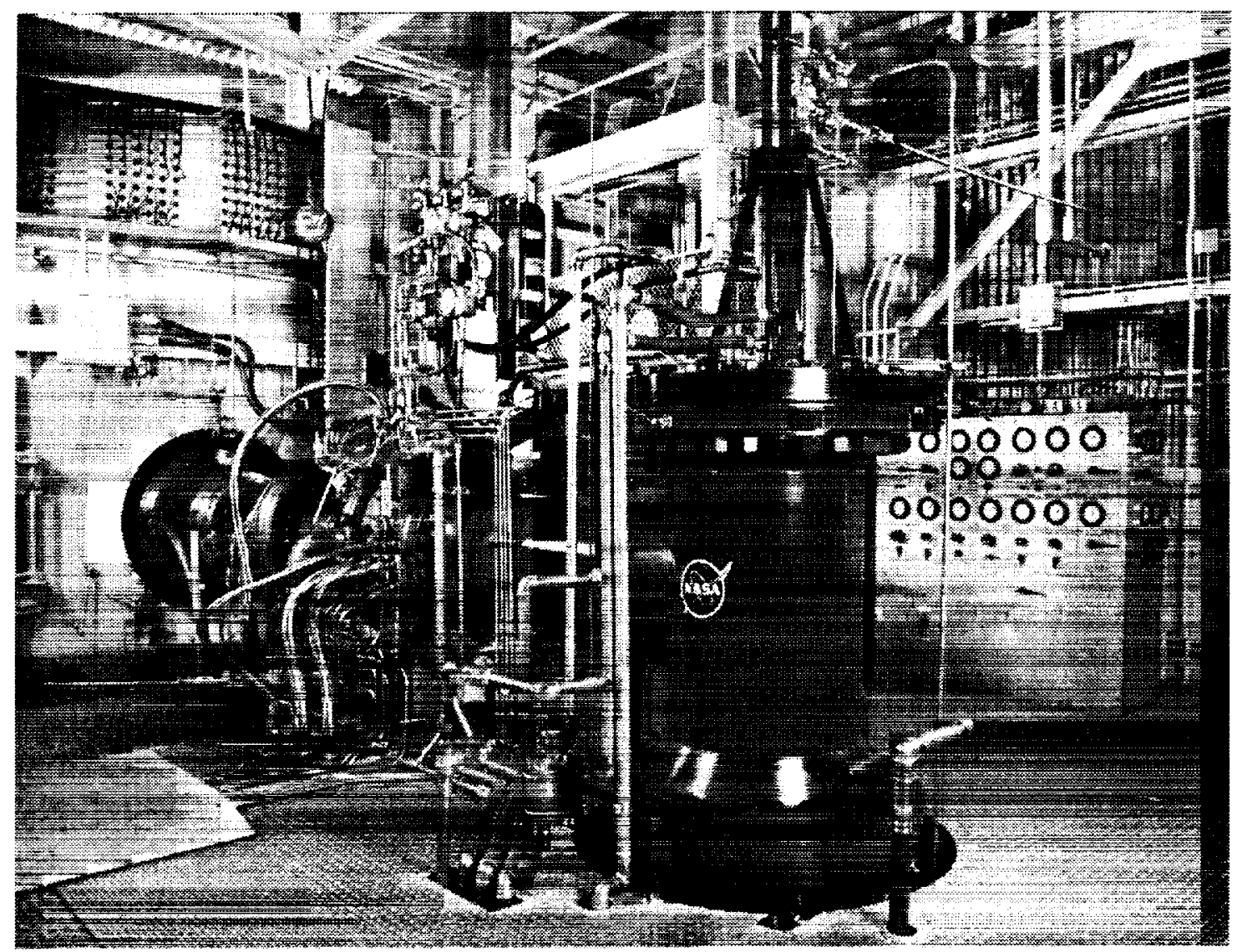

Figure 11.-HTF Hot Train assembly as of January 2000. (View from behind the Hot Tee, looking towards the Test Cabin) 

Davis Highway, Sutte 1204, Arlington, VA 22202-4302, and to the Office of Management and Budget, Paperwork Reduction Project (0704-0188), Washington, DC 20503.

\begin{tabular}{|c|c|c|}
\hline 1. AGENCY USE ONLY (Leave blank) & $\begin{array}{l}\text { 2. REPORT DATE } \\
\text { March } 2000\end{array}$ & $\begin{array}{l}\text { 3. REPORT TYPE AND DATES COVERED } \\
\text { Technical Memorandum }\end{array}$ \\
\hline
\end{tabular}

\section{TITLE AND SUBTITLE}

5. FUNDING NUMBERS

Restoration of the Hypersonic Tunnel Facility at NASA Glenn

Research Center, Plum Brook Station

6. AUTHOR(S)

WU-282-20-02-02

Mark A. Woodling

7. PERFORMING ORGANIZATION NAME(S) AND ADDRESS(ES)

National Aeronautics and Space Administration

John H. Glenn Research Center at Lewis Field

Cleveland, Ohio 44135-3191

8. PERFORMING ORGANIZATION REPORT NUMBER

E-12174

\section{SPONSORINGMONITORING AGENCY NAME(S) AND ADDRESS(ES)}

National Aeronautics and Space Administration

Washington, DC 20546-0001

SPONSORING/MONITORING AGENCY REPORT NUMBER

NASA TM-2000-209930

AIAA-2000-0163

11. SUPPLEMENTARY NOTES

Prepared for the 38th Aerospace Sciences Meeting and Exhibit sponsored by the American Institute of Aeronautics and Astronautics, Reno, Nevada, January 10-13, 2000. Responsible person, Mark A. Woodling, organization code 7515, (216) 433-5430.

12a. DISTRIBUTION/AVAILABILITY STATEMENT

12b. DISTRIBUTION CODE

Unclassified - Unlimited

Subject Category: 09

Distribution: Nonstandard

This publication is available from the NASA Center for AeroSpace Information, (301) 621 -0390

13. ABSTRACT (Maximum 200 words)

The NASA Glenn Research Center's Hypersonic Tunnel Facility (HTF), located at the Plum Brook Station in Sandusky, Ohio, is a non-vitiated, free-jet facility, capable of testing large-scale propulsion systems at Mach Numbers from 5 to 7. As a result of a component failure in September of 1996, a restoration project was initiated in mid-1997 to repair the damage to the facility. Following the 2-1/2 year effort, the HTF has been returned to an operational condition. Significant repairs and operational improvements have been implemented in order to ensure facility reliability and personnel safety. As of January 2000 , this unique, state-of-the-art facility was ready for integrated systems testing.

14. SUBJECT TERMS

Hypersonic; Ground testing; Rehabilitation

15. NUMBER OF PAGES 19

16. PRICE CODE

$\mathrm{A03}$

\begin{tabular}{|c|c|c|c|}
\hline $\begin{array}{c}\text { 17. SECURITY CLASSIFICATION } \\
\text { OF REPORT } \\
\text { Unclassified }\end{array}$ & $\begin{array}{c}\text { 18. SECURITY CLASSIFICATION } \\
\text { OF THIS PAGE } \\
\text { Unclassified }\end{array}$ & $\begin{array}{c}\text { 19. SECUAITY CLASSIFICATION } \\
\text { OF ABSTRACT } \\
\text { Unclassified }\end{array}$ \\
\hline
\end{tabular}

NSN 7540-01-280-5500 